\title{
Young driver perceptions of police traffic enforcement and self reported driving offences
}

\author{
Lyndel Bates*
}

School of Criminology and Criminal Justice and Griffith Criminology Institute, Griffith University, Brisbane, Australia

Centre of Accident Research and Road Safety - Queensland (CARRS-Q), Institute for Health and Biomedical Innovation, Queensland University of Technology, Brisbane, Australia

Email: 1.bates@griffith.edu.au

Phone: 61737351429

Bridie Scott-Parker

Adolescent Risk Research Unit (ARRU), School of Social Sciences, University of the Sunshine Coast, Queensland, Australia

Siobhan Allen

School of Criminology and Criminal Justice, Griffith University, Brisbane, Australia Barry Watson

Global Road Safety Partnership, Geneva, Switzerland

Centre of Accident Research and Road Safety - Queensland (CARRS-Q), Institute for Health and Biomedical Innovation, Queensland University of Technology, Brisbane, Australia

*Corresponding Author 


\section{Young driver perceptions of police traffic enforcement and self reported driving offences}

Purpose: Road policing is a key method used to improve driver compliance with road laws. However, we have a very limited understanding of the perceptions of young drivers regarding police enforcement of road laws. This paper addresses this gap.

Design/Methodology/Approach: Within this study 238 young drivers from Queensland, Australia, aged 17-24 years $(M=18, S D=1.54)$, with a provisional (intermediate) driver's licence completed an online survey regarding their perceptions of police enforcement and their driver thrill seeking tendencies. This study considered whether these factors influenced self-reported transient (e.g., travelling speed) and fixed (e.g., blood alcohol concentration) road violations by the young drivers.

Findings: The results indicate that being detected by police for a traffic offence, and the frequency with which they display P-plates on their vehicle to indicate their licence status, are associated with both self-reported transient and fixed rule violations. Licence type, police avoidance behaviours and driver thrill seeking affected transient rule violations only, while perceptions of police enforcement affected fixed rule violations only.

Practical implications: This study suggests that police enforcement of young driver violations of traffic laws may not be as effective as expected and that we need to improve the way in which police enforce road laws for young novice drivers.

Originality/value: This paper identifies that perceptions of police enforcement by young drivers does not influence all types of road offences.

Keywords: road policing; traffic law enforcement; teen driver; graduated driver licensing; novice driver; violations

Paper type: Research paper

\section{Introduction and Literature Review}

Road policing is an integral component of programs used to ensure that drivers comply with traffic laws (Bates, 2014; Bates, Soole, \& Watson, 2012; Stanojevic, Jovanovic, \& Lajunen, 2013). Policing and enforcement programs are used to modify a 
wide range of driver behaviors including drink driving, drug driving, speeding, red light running and seat belt use (Bates et al., 2012; Bertelli \& Richardson Jr., 2008; Nichols \& Ledingham, 2008; Watling, Palk, Freeman, \& Davey, 2010). The time of day may also affect the effectiveness of enforcement activities such as campaigns to reduce speeding by drivers (Vaa, 1997). As well as targeting specific driver behaviors, sometimes road policing can be used to manage the behavior of particular road user groups including motorcyclists (e.g. Hyder, Waters, Phillips, \& Rehwinkel, 2007) and cyclists (e.g. Johnson, Charlton, Oxley, \& Newstead, 2013). Given the high crash rates associated with young drivers, there may be benefits in using enforcement to help increase this group's compliance with driving laws (Bates, Allen, et al., 2014).

\section{Young drivers}

Road crashes cause a significant number of deaths and injuries to road users (Prenzler, Manning, \& Bates, 2015). When compared with other groups of drivers, young drivers have the highest crash rates (Bates, Davey, Watson, King, \& Armstrong, 2014; Williams, 2003) and this pattern is consistently replicated throughout the world (Elvik, 2010). To illustrate in the Australian and New Zealand context, drivers aged 18 years sustained the most injuries and fatalities in road crashes during the inclusive period 2001-2010 (Bradshaw, Turner, Makwasha, \& Cairney, 2015). In Queensland, Australia, $13.9 \%$ of 2014 road crash fatalities and $18.3 \%$ of hospitalized casualties involved a driver aged 17-20 years (Queensland Department of Transport and Main Roads, 2015a), despite these drivers comprising 6.2\% of the licensed population (Queensland Department of Transport and Main Roads, 2015b). During 2014, 11.2\% of road crash fatalities and $20.1 \%$ of hospitalized casualties involved a driver with a provisional (intermediate) driver's licence (Queensland Department of Transport and Main Roads, 
2015a), despite these drivers comprising 6.0\% of the licensed population (Queensland Department of Transport and Main Roads, 2015b). This crash risk is related to inexperience-related factors such as an underdeveloped ability to perceive and react appropriately to driving hazards, age, gender and other reasons such as the carriage of passengers that are of a similar age to themselves, mobile phone use and personality factors amongst others (see for example: Bates, Davey, et al., 2014; Shope, 2006).

Young drivers report engaging in risky behavior which appears to be related to sensation seeking tendencies (e.g., Begg \& Langley, 2004; Scott-Parker, Stokes, Nelson, \& Josland, under review). Driving behaviors related to sensation seeking is problematic for road safety, as the young driver may drive in a more risky manner to experience the accompanying thrill (Scott-Parker, 2012). Sensation seeking and associated thrill seeking has been found to contribute to risky driving by young novice

drivers more generally (e.g., speeding, Scott-Parker, Hyde, Watson, \& King, 2013), and to crashes and offences specifically (e.g., Blows, Ameratunga, Ivers, Lo, \& Nortan, 2005; Rimmo \& Aberg, 1999).

\section{Graduated Driver Licensing}

The countermeasure that is used most frequently to reduce the crash rates for this group is graduated driver licensing (GDL). As noted by Foss (2007), this approach reduces crashes by focusing on the risk for these people as a group, consistent with the 'young driver problem', rather than the risk of individual drivers which is consistent with the 'problem young driver' (Scott-Parker, Watson, King, \& Hyde, 2013). The philosophy of GDL is to allow novice drivers to obtain driving experience in less risky situations (Williams \& Shults, 2010). There are typically three stages in a GDL system: learner, 
provisional (intermediate), and the full (open) licence (Bates, Allen, et al., 2014). The learner phase enables new drivers to acquire driving competency under the supervision of a more proficient driver while a provisional licence allows the novice driver to drive independently subject to restrictions (Bates, Allen, et al., 2014; Preusser \& Leaf, 2003). Evaluations have shown that the introduction of GDL in the United States of America has reduced crash risk for the youngest novice drivers by $20-40 \%$ (Shope, 2007). An evaluation of the introduction of a more comprehensive GDL system within Queensland, Australia, also indicated that crashes for novice drivers have reduced (Newstead \& Scully, 2013).

\section{GDL enforcement}

Similar to other measures designed to reduce the severity and incidences of road crashes, enforcement of GDL-specific rules is required. It appears, however, that the enforcement of GDL programs does not occur in a systematic manner. Most parents and the majority of adolescent participants in a study conducted within North Carolina indicated that they did not know if the police enforced the provisions of a GDL system (Goodwin \& Foss, 2004). Additionally, it is difficult for police to enforce GDL systems if they are either unaware of the specific provisions or are unable to identify drivers that hold a provisional licence (Bates, Allen, et al., 2014). As a result, it appears that parents are implicitly expected to enforce GDL provisions for their children, at least in the United States of America (Williams, Leaf, Simons-Morton, \& Hartos, 2006). In Australia, the use of L- and P- plates on vehicles are designed to facilitate the enforcement of GDL provisions by police officers by clearly indicating to police and other road users the drivers' licence status. 
While crashes are more likely to occur immediately after a young driver obtains their provisional licence, traffic conviction rates appear to increase steadily over time. Research using the traffic conviction data of 16 and 17 year old licensed drivers from California suggest that conviction rates peak at around 18 years of age with only 45 per cent of the sample remaining conviction-free for the first three years of driving without a supervisor (Chapman, Masten, \& Browning, 2014). Research in South Australia found that $15.6 \%$ of 49,536 young drivers had at least one driving offence recorded in a government database during the first year of driving (Kloeden, 2008). Research using a self-report methodology, conducted with a sample of young Queensland drivers suggests that, as drivers progress through the licensing system, they are less likely to comply with general road rules and more likely to engage in risky driving behaviors (Scott-Parker, Watson, King, \& Hyde, 2012b). More recent research in Queensland suggests a similar pattern (Allen, Murphy, \& Bates, 2015, online first).

Masten, Chapman, Atkinson, and Browning (2014) examined the conviction rate for young provisional drivers within California. They obtained traffic conviction records for nearly 1.5 million young drivers who were aged 16 or 17 years when they obtained their provisional driving licence between 1 January 2001 and 31 December 2007. In contrast to studies that use self-report methodologies exploring enforcement experiences (e.g. Goodwin \& Foss, 2004), the authors of this study found that young drivers were rarely convicted of violating GDL requirements (Masten et al., 2014). This may be because young drivers report a variety of mechanisms to prevent receiving a conviction for violating GDL requirements or the road rules more broadly. This suggests that there is a need to understand, and possibly improve, the enforcement processes used for young novice drivers. 


\section{Study context}

The Queensland GDL system allows individuals to obtain their learner licence from 16 years of age. Learner drivers need to record 100 hours of supervised practice in a log book and must always drive under the supervision of a more experienced driver (Bates, Watson, \& King, 2014; Scott-Parker, Bates, Watson, King, \& Hyde, 2011). After completing a practical driving test, and when they are aged at least 17 years, the individual is then able to obtain their first provisional (P1) licence. P1 drivers must display a red P plate on the front and rear of their vehicle to indicate their licence status. Additionally, they are limited to carrying no more than one peer-aged passenger between $11 \mathrm{pm}$ and 5am. P1 drivers must be aged at least 18 years and pass the hazard perception test in order to advance to the second provisional (P2) licence. P2 drivers must display a green $\mathrm{P}$ plate on the front and rear of their vehicle to indicate their licence status. Both P1 and P2 drivers must have a zero blood alcohol content (BAC) while driving and are unable to use their mobile phone at all, including hands-free functions, while driving (Senserrick, 2009). This paper examines young driver perceptions of police enforcement of various traffic laws and the relationship between these perceptions on young drivers violating both GDL-specific and more general driving laws.

\section{Methods}

\section{Participants and procedure}

Participants in the study were provided with information regarding the research before commencing the anonymous online survey. Submission of a completed survey indicated that respondents consented to participate in the study. The study was approved by the 
Queensland University of Technology Human Research Ethics Committee

(13000000542) before the survey opened with data collection occurring between 11 October 2013 and 20 June 2014.

The 238 participants in this study were recruited through an undergraduate research pool, flyers and email lists from a major Queensland university. The undergraduate research pool provides students with the opportunity to gain course credit for their participation in research. It is not possible to calculate a response rate as the exact number of participants who learnt about the study from the research pool, flyers and email lists is not known. Only participants driving on a provisional licence were included in this study. As some participants $(n=22)$ did not answer every question, they were excluded from the analysis. Each participant completed a 30 minute online survey where they reported their perceptions of driving behavior and compliance with road rules. The study reported here is part of a larger program of research examining young driver perceptions of road policing (Bates, Allen, \& Watson, in press; Bates, Darvell, \& Watson, 2015, online first).

\section{Measures}

A range of measures were operationalized in the online survey including the independent variables socio-demographic characteristics, driver thrill seeking, selfreported police avoidance, $\mathrm{p}$-plate display, apprehension and perceptions of police responses. The dependent variables were transient and fixed violations.

\section{Independent variables}

Socio-demographic items measured in this study include age $(M=18, S D=1.54)$, gender $(0=$ male; $1=$ female $)$, and licence type $(0=\mathrm{P} 1 ; 1=\mathrm{P} 2)$. A scale, originally adapted 
from a sub-scale in the driver thrill-seeking measure (Matthews, Desmond, Joyner, Carcary, \& Kirby, 1997) was included in this study. It was more recently used in novice driver research by Bates (2012). This eight item survey was measured on a Likert scale of 1 (do not agree at all) to 11 (agree strongly) and asked participants questions based on their usual or typical feelings about driving. Those who scored higher on the scale exhibited higher levels of driver thrill seeking. Example items included "I would like to risk my life as a racing car driver"; "I get a real thrill out of driving fast"; "I enjoy cornering at high speed". The driver thrill seeking scale has good internal consistency, with Bates' (2012) study on provisionally licensed drivers reporting a Cronbach alpha coefficient of $\alpha=.86$. In the current study the Cronbach alpha coefficient for the driver thrill seeking scale was $\alpha=.87$.

Self-reported police avoidance was measured using a single item adapted from ScottParker (2012). The item asked participants "Do you avoid the areas where you know police are, or are likely to be?". This question was used to identify if differences in selfreported driving behaviors existed between those who reported avoiding police detection and those who did not. Participants could respond with either a yes (1) or a no (2). The split between those who reported avoiding police and those who did not was $36.3 \%$ and $61.7 \%$ respectively. This is similar to that of Scott-Parker's (2012) study where $38 \%$ of $\mathrm{P} 1$ drivers reported actively avoiding police.

As noted earlier, a requirement for all provisionally licenced drivers in the Queensland GDL system is to display P-plates on the front and rear of the vehicle driven by a provisionally licensed driver. The question "How often do you display P-plates?" was asked with participants able to respond nearly all the time (82.2\%), usually (6.1\%), sometimes (2.0\%), occasionally (6.1) and never (2.4\%). 
Self-reported apprehension was measured using a single item from Scott-Parker's (2012) research on young drivers. This single item asked participants "Have you been caught committing any driving offences while you have had a provisional licence?". Participants could respond with either a yes (1) or a no (2). In this study, $22.4 \%$ of participants reported being previously apprehended by police which is similar to ScottParker's (2012) research in which $21.1 \%$ of young P1 drivers reported that they had previously been caught committing a driving offence.

The 19 item police enforcement scale was designed specifically for this this study. The survey asked participants to answer on a Likert scale from 1 (never) to 5 (nearly all the time) questions regarding how often they think police officers enforce a range of scenarios. Those who scored higher on this scale indicated that they perceive police enforcing the road rules with greater frequency. Example scenarios include "Driving under the influence of an illicit drug such as marijuana or ecstasy"; "Undertaking an illegal U-turn"; and "Driving a high-powered vehicle". The police enforcement scale demonstrated good internal consistency with a Cronbach alpha coefficient of $\alpha=.96$. Table 1 provides the descriptive statistics for the sample as they relate to each of the independent variables.

\section{Dependent variables}

The Behaviour of Young Novice Drivers Scale (BYNDS) was taken from Scott-Parker and colleague's $(2012 ; 2010)$ research on the risky driving behavior of young novice drivers. This scale has five subscales of driving behavior; transient violations, fixed violations, misjudgment, risky driving exposure and driving in response to their mood. As the focus of this study was on young driver compliance, we only used the transient violations and fixed violations subscales. 
The transient violations subscale was designed by Scott-Parker et al. (2010) to measure road violations that can be made more than once in one trip. The subscale originally contained 13 items however one additional item ("You texted on your mobile phone while driving") was included in the current study. Those who scored higher on the scale indicated more engagement in self-reported transient rule violations. Participants responded to questions regarding how often they engaged in a range of behaviors on a five point Likert scale from (1) never to (5) nearly all the time. Example questions included "You did an illegal U-turn"; "You deliberately sped when overtaking"; and "You went more than $20 \mathrm{~km} / \mathrm{h}$ over the speed limit". Given that the participants targeted were young novice drivers and research suggests that a high proportion of young drivers use a mobile phone while driving (Gauld, Lewis, Haque, \& Washington, 2015), the addition of the transient violation item regarding mobile phone behavior seemed appropriate to add to the scale without diminishing its internal consistency.

Scott-Parker's (2012) research indicates that the transient rule violations scale has good internal consistency, reporting a Cronbach alpha coefficient of $\alpha=.89$. This study, with the addition of the one item regarding mobile phone use, produced a Cronbach alpha coefficient of $\alpha=.91$. Whilst it is not ideal to compare scales that have been modified, this comparison suggests that the transient violations subscale used in this study was psychometrically similar to the original scale designed by Scott-Parker and colleagues.

The fixed violations scale contains ten items designed to measure violations that are stable in nature while driving (Scott-Parker et al., 2010). Participants with higher scores on this scale indicated that they violate fixed rules to a greater degree. Example items from this scale include "You carried more passengers than there were seatbelts for in your car"; and "You drove after taking an illicit drug such as marijuana or ecstasy". 
According to Scott-Parker (2012), the BYNDS fixed violations subscale has good internal consistency, with a Cronbach alpha coefficient of $\alpha=.75$. The same subscale in this study had a Cronbach alpha coefficient of $\alpha=.85$. There is a moderate correlation between fixed rules violations and transient rule violations $(r=.5, p<.001)$. Table 1 provides the descriptive statistics for the dependent variables as they related to the sample.

\section{Results}

The aim of this study was to examine the influence of perceptions of police enforcement activity on young driver behavior, particularly fixed and transient rule violations. Participants were aged between 17 and 24 years with a mean age of 18 years $(S D=$ 1.54). While the majority were female $(71.9 \%)$, there was a relatively even divide between those holding a P1 licence (53.8\%) and those on a P2 licence (46.2\%). Most of the sample had access to a vehicle with $69.6 \%$ reporting that they owned a car. Of those that did not own a car, $81.9 \%$ indicated that they had access to a car for regular driving (at least three times per week). Participants reported driving for between 0 and 30 hours per week $(M=6.22, s d=4.8)$.

Table 2 shows participants self-reported offending behaviors on the road. There is extremely high compliance for all of the items in the fixed violations subscale. Seven of the 10 items had over $90 \%$ of the sample indicating that they never engaged in the behavior (e.g. you drove after taking an illicit drug such as marijuana or ecstasy; you didn’t always wear a seatbelt). In contrast, more young drivers within the sample reported that they engaged in transient offences (e.g. you drove over the speed limit in areas where it was unlikely there was a radar or camera).

\section{[Insert Table 2 about here]}


Table 3 reports how frequently young drivers perceive that police enforce the road laws. The responses pertaining to more serious violations, such as excessive speeding, running a red light, driving under the influence of illicit drugs or alcohol, using a mobile phone while driving, or not having a valid driver's licence, indicate that participants believe that police enforce those rules much more often than those relating to less serious violations such as performing an illegal U-turn, driving a high powered vehicle, having an illegible licence plate and not displaying their P-plates.

\section{[Insert Table 3 about here]}

In order to examine the relationship between perceptions of police enforcement and young driver behavior, two regressions were performed: one using self-reported transient violations as the dependent variable and the other using fixed rule violations. Within the regression, the variables age, gender, licence type, self-reported police avoidance and apprehension as well as the frequency with which participants reported displaying P-plates were entered in the first step.

The results in Table 4 suggest that licence type, self-reported police avoidance, being previously caught by police and the frequency with which P-plates are displayed influence transient rule violations, $R^{2}=.27, F(6,227)=13.74, p<.001$. In the second step the variables driver thrill seeking and perceptions of police enforcement were included. The inclusion of these two variables increased the explained variance, $R^{2}=.35, F(2$, $225)=14.73, p<.001$.

\section{[Insert Table 4 about here]}

This regression suggests that provisionally licensed drivers on a P2 licence are more likely to report that they engage in transient rule violations when compared with 
provisionally licensed drivers on a P1 licence. Additionally, those who indicated that they avoided police and those who reported being caught by police previously were more likely to report breaking transient road rules. Finally, the drivers who reported displaying their P-plates on their vehicles more frequently were less likely to break transient road rules. The addition of the driver thrill seeking and police enforcement variables into the model, suggests that those participants with high driver thrill seeking tendencies were more likely to report breaking transient road rules. Perceptions of police enforcement was not a significant predictor.

The second regression had fixed rule violations as the dependent variable. Age, gender, licence type, self-reported police avoidance, whether the participant had been previously caught by police and the frequency with which they displayed their P-plates were entered into the first step. As shown in Table 5, this first step was significant, $R^{2}=.16, F(6,227)=6.94, p<.001$, with self-reported instances of being previously caught and frequency of P-plate display significant predictors. In the second step the variables measuring driver thrill seeking and police enforcement were added, $R^{2}=.20, F(2$, $225)=6.02, p<.01$. Perceptions of police enforcement was a significant predictor while driver thrill seeking approached significance. Thus, it appears that participants who reported being previously caught by police and displaying their P-plates with less frequency were more likely to report violating fixed rules. Those who perceived that police officers frequently enforce traffic rules were less likely to report violating fixed rules.

\section{[Insert Table 5 about here]}

\section{Discussion}

Enforcement is one component of changing driving behavior (Bates et al., 2012; Shinar, 
1993). Prior research suggests that GDL systems are an effective countermeasure to reduce young driver crashes (Shope, 2007). This is despite very few young drivers being convicted of violating GDL provisions (Masten et al., 2014), and at the same time, young drivers reporting that they become less compliant as they progress through the driver licensing system from a learner driver to an independent driver (Allen et al., 2015, online first; Scott-Parker et al., 2012b). Given that it appears that young drivers are less likely to comply with road laws the further they progress through the licensing system, there is a need to explore provisional drivers' perceptions of enforcement in order to develop more effective countermeasures. Prior studies have not considered the different categories of violations.

This study did not find any difference between the two licence groups on fixed rule violations such as carrying more passengers than there were seatbelts in the car and driving after taking illicit drugs, while there was a difference for self-reported transient rule violations such as speeding or using a mobile phone. Thus, it appears that there is a difference in young driver engagement in transient and fixed rule violations. This is supported by the descriptive data in Table 2 which suggests that, generally, there are higher levels of self-reported compliance with fixed offences.

The results of this study indicate that young drivers with a provisional license perceived that police officers enforced certain types of offences more frequently. Offences that they believed were enforced more frequently by police included high range speeding offences (more than $20 \mathrm{~km} / \mathrm{hr}$ over the posted speed limit), driving under the influence of illegal drugs and alcohol, and driving through an intersection when the traffic light was red. Offences that they perceived were enforced with less frequency were not displaying either a red or a green P-plate or undertaking an illegal U-turn. Perceptions 
regarding the high frequency of enforcement for offences such as driving under the influence of alcohol may be a result of specific enforcement campaigns based on the principles of deterrence that are designed to create the perception within the driving community that enforcement is frequent (Bates et al., 2012). For instance, in Queensland there is one random breath test conducted for every licensed driver per year (Ferris et al., 2013) meaning there were 3.9 million RBTs conducted in Queensland in 2014 (Scott-Parker et al., under review). Prior research regarding drink driving in the United States suggests that there is no one approach that will change the behavior of all drivers. However, changing driver perceptions regarding the enforcement of laws is likely to deliver the most effective reductions in drink driving (Bertelli \& Richardson Jr., 2008). The time of day may also affect the effectiveness of enforcement with drivers less likely to change their speeding behavior during the morning commute (Vaa, 1997).

It is difficult to identify provisionally licensed drivers apart from their physical drivers' licence and their compulsory P-plates. Therefore, this finding regarding provisional driver perceptions' of the frequency with which certain offences are enforced may reflect the difficulty inherent in police officers doing this for traffic laws that apply to a limited number of drivers. For effective enforcement, it is necessary for police officers to be aware of the various driving requirements. However, previous research conducted in North Carolina within the United States of America suggests this is not always the case. In that study, interviews with police officers revealed that, while they were supportive of GDL, they were not aware of the finer details of the licensing provisions (Goodwin \& Foss, 2004).

Those provisional drivers who displayed P-plates with less frequency or had been previously caught committing a traffic offence were more likely to report lower 
compliance with both fixed and transient rule violations. The failure to display P-plates consistently may make drivers believe that the police will find it difficult to identify them as provisional drivers. As a result, they may feel more comfortable in violating traffic rules. In contrast, the 'emboldening' effect of provisional drivers being more likely to report violating both fixed and transient rules if they have been previously caught by police is counter-intuitive. The finding that experiences with enforcement lead to an increase in the undesirable behavior has been found in previous studies (Bates et al., 2015, online first; Fleiter \& Watson, 2006; Piquero \& Pogarsky, 2002) and may be a result of the actual experience of enforcement not being as unpleasant as initially perceived. In addition, many driving offences committed by the drivers may have remained undetected, therefore the comparatively few enforcement experiences may be of limited effect (e.g. Scott-Parker \& Bates, under review).

Prior research has identified that provisional drivers who report avoiding police are more likely to engage in risky driving behaviors (Scott-Parker, Watson, King, \& Hyde, 2011). Within the current study, avoiding police was associated with a self-reported increase in the likelihood that the provisional driver would break transient road rules such as posted speed limits, but not fixed rules like zero blood alcohol concentrations. This may be because provisional drivers believed that, if they made a conscious effort to avoid police, they would be able to engage in more transient violations which may be haphazardly enforced (such as increasing travelling speed when the traffic lights changed from green to yellow), in comparison to fixed violations which may be enforced in a more coordinated fashion (for example, driving after drinking alcohol).

Individuals with higher driver thrill seeking tendencies were more likely to report transient rule violations and this approached significance for fixed rule violations. This 
reveals the influential role of psychological factors upon the on-road behavior of provisional drivers, and this finding is consistent with previous research (e.g. Begg \& Langley, 2004; Blows et al., 2005; Rimmo \& Aberg, 1999; Scott-Parker, Hyde, et al., 2013). As such, interventions developed to reduce road rule violations, and transient rule violations in particular by novice drivers, should consider the inherent 'thrills' experienced as a result of behaviors like speeding, racing out of intersections, and driving too fast around a corner (Scott-Parker et al., 2012b; Scott-Parker, Watson, et al., 2013).

Self-reported perceptions of police enforcement was statistically significant for fixed rule violations but not for transient rule violations. It is possible that provisionally licensed drivers perceive that police are able to enforce fixed rule violations such as driving under the influence of drugs or carrying more passengers than there are seat belts in the vehicle with greater ease and success. As a result, they are less likely to engage in these behaviors. In contrast, participants may perceive that it is more difficult for police to enforce transient behaviors such as texting on a mobile phone while driving or speeding. As a result, they engage in these type of behaviors more frequently.

\section{Implications}

This study suggests that the effect of police enforcement of traffic laws for provisional drivers is nuanced. This will affect the way that the police enforce the road rules for this group. This research, in conjunction with other research (Allen et al., 2015, online first; Bates et al., 2015, online first), suggests that, at least for some types of offences such as transient rule violations, the effect of police enforcing traffic laws is not as effective in reducing young driver violations as maybe perceived. As a result, there is a need to change the way that police themselves enforce these laws. Given that those drivers who 
display P-plates with the greatest frequency are less likely to report violating road laws, it is possible that greater focus on ensuring provisionally licensed drivers are displaying their P-plates may lead to greater compliance with other laws.

Additionally, police could work with other parties to help modify behaviors in young drivers. This could involve using a third party policing model. Third party policing involves the police working with other groups or organizations to help enforce various laws. Some type of legal lever assists with this process (Mazerolle \& Ransley, 2005). In this context, police may be able to work with the parents of provisional drivers more effectively to ensure that the number of road law violations by provisionally licensed drivers is reduced.

The manner in which police enforce road laws with provisional drivers may also be important. One focus group study suggested that a young person's single interaction with a police officer in a road context had a strong effect on their perceptions of police (Scott-Parker \& Bates, under review). Procedural justice is an important yet largely overlooked issue in the area of road policing (Bates, 2014). The concept relates to how police interact with people and whether they communicate a sense of trust, neutrality, voice and respect (Murphy, Mazerolle, \& Bennett, 2014). Interactions characterized by these principles have been found to lead to higher levels of cooperation (Bradford, 2014) and trust (Tyler, 2005) in police, and, importantly, future intentions to comply with road rules (Barkworth \& Murphy, 2015). Additionally, given that provisional drivers who report avoiding police report that they are more likely to commit a transient rule violation, it is important that parents and friends do not support this process. Parents and friends could do this either directly (e.g., by incurring the penalty points) or indirectly (e.g., by informing the young driver of on-road enforcement activity) (Scott- 
Parker \& Bates, under review; Scott-Parker, Watson, et al., 2011; Scott-Parker, Watson, King, \& Hyde, 2012a).

\section{Limitations and Future Research}

While this study makes an important contribution to our understanding of provisional driver perceptions of police enforcement, there are some limitations. Most of the sample within this study were university students studying psychology at a major Australian university which may make it difficult to generalize the results of this study beyond this group. Additionally, the measures used within this study are based on self-report. Jerolmack and Khan (2014) argue that the use of methodologies, such as surveys, that ask participants to self-report their attitudes and behaviors do not necessary explain individuals' actions as these are very personal. However, given that this study is exploring young driver perceptions of police enforcement, it is appropriate to use a selfreport methodology for this study particularly given that prior research regarding young drivers and the self-report of police-recorded crashes and offences indicates a high level of accuracy (Boufous et al., 2010). However, future research should build upon this work by using alternative methodologies.

This study considered perceptions of police enforcement and the impact of these perceptions on self-reported driving violations. However, this study did not consider the perceived seriousness of penalties for committing these violations. It is possible that the type of penalty issued to provisional drivers who break road laws affects their behavior. It would therefore be appropriate to examine the effect of perceptions of the seriousness of penalties issued for various types of driving offences in future research, particularly as the nature of penalties differ according to offence type (e.g., drink driving cf speeding), and magnitude of offence (e.g, low-range cf high-range). 
This is one of the first investigations into provisional driver perceptions of police enforcement regarding different violation types. Thus, there is a need for further research regarding the terms of the relationship between perceptions of enforcement and violations in general, and potential differences between types of violations. This is warranted given that experience with enforcement was a significant predictor for fixed but not transient violations.

\section{Conclusion}

GDL systems have been a successful public health approach to reducing the high rates of young driver crashes after they commence driving by themselves. However, compliance rates with road rules declines the longer a young driver holds their driver's licence. As a result, we need to consider how to modify young driver behavior to encourage compliance with these laws. Traditionally, road policing is a key mechanism to encourage compliance with road laws. However, very little is known about young driver perceptions of police enforcement of traffic laws.

This study suggests that the effectiveness of police enforcement for young drivers is a nuanced process. Young driver perceptions of police enforcement were found to affect self-reported fixed rule violations. This finding suggests that there may be changes needed in the way police enforce transient rules like posted speed limits, or that alternative enforcement models, such as third party policing, should be considered. The implications of this study are that police may wish to alter some of their enforcement strategies for this group. This could include encouraging more frequent displays of Pplates, developing third party policing strategies and ensuring that any dealings with young drivers are fair and equitable. 


\section{References}

Allen, S., Murphy, K., \& Bates, L. (2015, online first). What drives compliance? The effect of deterrence and shame emotions on young drivers' compliance with road laws. Policing and Society. doi: 10.1080/10439463.2015.1115502

Barkworth, J., \& Murphy, K. (2015). Procedural justice policing and citizen compliance behaviour: the importance of emotion. Psychology, Crime \& Law, 21(3), 254273. doi: 10.1080/1068316X.2014.951649

Bates, L. (2012). The experience of learner driver, provisional drivers and supervisors with graduated driver licensing in two Australian jurisdictions. (Doctor of Philosphy), Queensland University of Technology, Brisbane, Queensland.

Bates, L. (2014). Procedural Justice and Road Policing: Is it important? Paper presented at the 2014 Australasian Road Safety Research, Policing \& Education Conference, Melbourne.

Bates, L., Allen, S., Armstrong, K., Watson, B., King, M., \& Davey, J. (2014). Graduated driver licensing: An international review. Sultan Qaboos University Medical Journal, 14(4), 403-412.

Bates, L., Allen, S., \& Watson, B. (in press). The influence of the elements of procedural justice and speed camera enforcement on young novice driver selfreported speeding. Accident Analysis \& Prevention.

Bates, L., Darvell, M., \& Watson, B. (2015, online first). Young and unaffected by road policing strategies: Using deterrence theory to explain provisional drivers' (non)compliance. Australian and New Zealand Journal of Criminology. doi: $10.1177 / 0004865815589824$

Bates, L., Davey, J., Watson, B., King, M., \& Armstrong, K. (2014). Factors contributing to young driver crashes: A review. Sultan Qaboos University Medical Journal, 14(3), 297-305.

Bates, L., Soole, D., \& Watson, B. (2012). The effectiveness of traffic policing in reducing traffic crashes. In T. Prenzler (Ed.), Policing and Security in Practice: Challenges and Achievements. Basingstoke: Palgrave Macmillan.

Bates, L., Watson, B., \& King, M. (2014). Parental perceptions of the learner driver log book system in two Australian states. Traffic Injury Prevention, 15(8), 809-816. 
Begg, D. J., \& Langley, J. (2004). Identifying predictors of persistent non-alcohol or drug-related risky driving behaviours among a cohort of young adults. Accident Analysis and Prevention, 26, 1067-1071. doi: 10.1136/ip.2007. 015925

Bertelli, A., \& Richardson Jr., L. (2008). The behavioral impact of drinking and driving laws. Policy Studies Journal, 36(4), 545-569. doi: 10.1111/j.15410072.2008.00283.x

Blows, S., Ameratunga, S., Ivers, R., Lo, S. K., \& Nortan, R. (2005). Risky driving habits and motor vehicle driver injury. Accident Analysis and Prevention, 37, 619-624. doi: 10.1016/j.aap.2005.03.003

Boufous, S., Ivers, R., Senserrick, T., Stevenson, M., Norton, R., \& Williamson, A. (2010). Accuracy of self-report of on-road crashes and traffic offences in a cohort of young drivers: the DRIVE study. Injury Prevention, 16, 275-277.

Bradford, B. (2014). Policing and social identity: procedural justice, inclusion and cooperation between police and public. Policing and Society: An international Journal of Research and Policy, 24(1), 22-43. doi:

$10.1080 / 10439463.2012 .724068$

Bradshaw, C., Turner, B., Makwasha, T., \& Cairney, P. (2015). Road fatalities and serious injuries in Australia and New Zealand 2001-10. Sydney: Austroads.

Chapman, E. A., Masten, S. V., \& Browning, K. (2014). Crash and traffic violation rates before and after licensure for novice California drivers subject to different driver licensing requirements. Journal of Safety Research, 50, 125-138. doi: 10.1016/j.jsr.2014.05.005

Elvik, R. (2010). Why some road safety problems are more difficult to solve than others. Accident Analysis \& Prevention, 42, 1089-1096.

Ferris, J., Mazerolle, L., King, M., Bates, L., Bennett, S., \& Devaney, M. (2013). Random Breath Testing in Queensland and Western Australia: What is the Optimum Ratio of Breath Testing to Licensed Drivers? Accident Analysis and Prevention, 60, 181-188.

Fleiter, J., \& Watson, B. (2006). The speed paradox: the misalignment between driver attitudes and speeding behaviour. Journal of the Australasian College of Road Safety, 17(2), 23-30.

Foss, R. (2007). Improving graduated driver licensing systems: A conceptual approach and its implications. Journal of Safety Research, 38(2), 185-192. 
Gauld, C., Lewis, I., Haque, M., \& Washington, S. (2015). Effect of mobile phone use and aggression on speed selection by young drivers: a driving simulator study. Journal of the Australasian College of Road Safety, 26(1), 40-46.

Goodwin, A. H., \& Foss, R. (2004). Graduated driver licensing restrictions: awareness, compliance, and enforcement in North Carolina. Journal of Safety Research, 35(4), 367-374.

Hyder, A., Waters, H., Phillips, T., \& Rehwinkel, J. (2007). Exploring the economics of motorcycle helmet laws -- Implications for low and middle-income countries. Asia-Pacific Journal of Public Health, 19(2), 16-22. doi: $10.1177 / 10105395070190020401$

Jerolmack, C., \& Khan, S. (2014). Talk is cheap: Ethnography and the attitudinal fallacy. Sociological Methods \& Research, 43(2), 178-209. doi: $10.1177 / 0049124114523396$

Johnson, M., Charlton, J., Oxley, J., \& Newstead, S. (2013). Why do cyclists infringe at red lights? An investigation of Australian cyclists' reasons for red light infringement. Accident Analysis \& Prevention, 50, 840-847. doi: 10.1016/j.aap.2012.07.008

Kloeden, C. (2008). The crash and offence experience of newly licensed young drivers. Sydney: Austroads.

Masten, S. V., Chapman, E., Atkinson, D., \& Browning, K. (2014). Non-compliance with graduated driver licensing (GDL) requirements: Changes in GDL-related conviction rates over time among 16-17-year-old California drivers. Accident Analysis \& Prevention, 72, 230-243. doi: 10.1016/j.aap.2014.07.008

Matthews, G., Desmond, P., Joyner, L., Carcary, B., \& Kirby, G. (1997). A comprehensive questionnaire measure of driver stress and affect. Traffic and transport psychology. Theory and application, 317-324.

Mazerolle, L., \& Ransley, J. (2005). Third Party Policing. Cambridge: Cambridge University Press.

Murphy, K., Mazerolle, L., \& Bennett, S. (2014). Promoting trust in police: findings from a randomised experimental field trial of procedural justice policing. Policing and Society: An international Journal of Research and Policy, 24(4), 405-424. doi: 10.1080/10439463.2013.862246 
Newstead, S., \& Scully, M. (2013). Crash effects of the new Queensland Graduated Licensing System: A preliminary evaluation. Paper presented at the 2013 Australasian Road Safety Research, Policing \& Education Conference, Brisbane, Australia.

Nichols, J., \& Ledingham, K. (2008). The impact of legislation, enforcement and sanctions on safety belt use (Vol. NCHRP Report 601). Washington, DC: Transportation Research Board.

Piquero, A., \& Pogarsky, G. (2002). Beyond Stafford and Warr's reconceptualization of deterrence: Personal and vicarious experiences impulsivity, and offending behavior. Journal of Research in Crime and Delinquency, 39, 153-186.

Prenzler, T., Manning, M., \& Bates, L. (2015). The implications of a harm perspective on terrorism, road safety, tobacco, alcohol, illicit drugs and workplace health and safety. Journal of Policing, Intelligence and Counter Terrorism, 10(2), 88101. doi: 10.1080/18335330.2015.1090050

Preusser, D., \& Leaf, W. A. (2003). Provisional license. Journal of Safety Research, 34, 45-49.

Queensland Department of Transport and Main Roads. (2015a). Comparative Queensland Road Toll Year to Date to 14 June 2015.

Queensland Department of Transport and Main Roads. (2015b). Current Queensland Driver's Licence. Retrieved 8 October 2015, from http://www.tmr.qld.gov.au/safety/transport-and-road-statistics/licensingstatistics.aspx

Rimmo, P.-A., \& Aberg, L. (1999). On the distinction between violations and errors: Sensation seeking associations. Transportation Research Part F, 2, 151-166. doi: 10.1016/S1369-8478(99)00013-3

Scott-Parker, B. (2012). A comprehensive investigation of the risky driving behaviour of young novice drivers. (Doctor of Philosophy), Queensland University of Technology, Queensland, Australia.

Scott-Parker, B., \& Bates, L. (under review). "...it just feels like you are a suspect for everything": Investigating young drivers' perceptions regarding their interactions with Police. Police Practice and Research: An international journal.

Scott-Parker, B., Bates, L., Watson, B., King, M., \& Hyde, M. (2011). The impact of changes to the graduated driver licensing program in Queensland, Australia on 
the experiences of learner drivers. Accident Analysis \& Prevention, 43, 13011308.

Scott-Parker, B., Hyde, M., Watson, B., \& King, M. (2013). Speeding by young novice drivers: What can personal characteristics and psychosocial theory add to our understanding? Accident Analysis and Prevention, 50, 242-250.

Scott-Parker, B., Stokes, L., Nelson, D., \& Josland, C. (under review). Are you okay to drive? Commuting behaviour and blood alcohol concentrations amongst restaurant diners. Addictive Behaviors.

Scott-Parker, B., Watson, B., \& King, M. (2010). The risky behaviour of young drivers: developing a measurement tool. Paper presented at the 20th Canadian Multidisciplinary Road Safety Conference, Nilton Niagara Falls, Ontario.

Scott-Parker, B., Watson, B., King, M., \& Hyde, M. (2011). Mileage, Car Ownership, Experience of Punishment Avoidance, and the Risky Driving of Young Drivers,. Traffic Injury Prevention, 12(6), 559-567.

Scott-Parker, B., Watson, B., King, M., \& Hyde, M. (2012a). “'They're lunatics on the road'': Exploring the normative influences of parents, friends, and police on young novices' risky driving decisions. Safety Science, 50, 1917-1928.

Scott-Parker, B., Watson, B., King, M., \& Hyde, M. (2012b). Young, inexperienced and on the road: do novice drivers comply with road rules? Transportation Research Record.

Scott-Parker, B., Watson, B., King, M., \& Hyde, M. (2013). Revisiting the concept of the 'problem young driver' within the context of the 'young driver problem': Who are they? Accident Analysis \& Prevention, 59, 144-152.

Senserrick, T. (2009). Australian graduated driver licensing systems. Journal of the Australasian College of Road Safety, 20(1), 20-26.

Shinar, D. (1993). Demographic and socioeconomic correlates of safety belt use. Accident Analysis \& Prevention, 25(6), 745-755.

Shope, J. T. (2006). Influences on youthful driving behavior and their potential for guiding interventions to reduce crashes. Injury Prevention, 12(suppl_1), i9-14.

Shope, J. T. (2007). Graduated driver licensing: Review of evaluation results since 2002. Journal of Safety Research, 38(2), 165-175. 
Stanojevic, P., Jovanovic, D., \& Lajunen, T. (2013). Influence of traffic enforcement on the attitudes and behavior of drivers. Accident Analysis \& Prevention, 52, 29-38. doi: 10.1016/j.aap.2012.12.019

Tyler, T. (2005). Policing in black and white: Ethnic group differences in trust and confidence in the police. Police Quarterly, 8(3), 322-342. doi: $10.1177 / 1098611104271105$

Vaa, T. (1997). Increased police enforcement: Effects on speed. Accident Analysis \& Prevention, 29(3), 373-385. doi: 10.1016/S0001-4575(97)00003-1

Watling, C., Palk, G., Freeman, J., \& Davey, J. (2010). Applying Stafford and Warr's reconceptualization of deterrence theory to drug driving: Can it predict those likely to offend? Accident Analysis \& Prevention, 42(2), 452-458. doi: http://dx.doi.org/10.1016/j.aap.2009.09.007

Williams, A. (2003). Teenage drivers: Patterns of risk. Journal of Safety Research, 34, 5-15.

Williams, A., Leaf, W. A., Simons-Morton, B., \& Hartos, J. L. (2006). Parents' views of teen driving risks, the role of parents, and how they plan to manage the risks. Journal of Safety Research, 37, 221-226.

Williams, A., \& Shults, R. A. (2010). Graduated Driver Licensing Research, 2007Present: A Review and Commentary. Journal of Safety Research, 41, 77-84. 
Table 1

Descriptive measures for continuous variables used within the study

\begin{tabular}{|c|l|l|l|l|}
\hline Independent variables & $\begin{array}{l}\text { No. of } \\
\text { items }\end{array}$ & Mean & SD & $\begin{array}{l}\text { Cronbach's } \\
\text { alpha }\end{array}$ \\
\hline Age $^{*}$ & & 18 & 1.54 & \\
\hline Driver thrill seeking $^{* *}$ & 8 & 29.79 & 15.02 & .87 \\
\hline Police enforcement scale $^{* * *}$ & 19 & 70.71 & 16.86 & .96 \\
\hline Dependent variables $^{\text {Transient violations subscale }}{ }^{* * *}$ & & & & \\
\hline Fixed violations subscale $^{* * *}$ & 14 & 2.11 & .69 & .91 \\
\hline & 10 & 1.16 & .34 & .85 \\
\hline
\end{tabular}

Not a scale item

${ }^{* *}$ Measured on a scale from 1 (do not agree at all) to 11 (agree strongly)

${ }^{* * *}$ Measured on a scale from 1 (never) to 5 (nearly all the time) 
Table 2

Self-reported young driver offending behavior (proportion, \%)

\begin{tabular}{rrrr}
\hline Never & $\begin{array}{r}\text { Occasio } \\
\text { nally }\end{array}$ & $\begin{array}{r}\text { Some- } \\
\text { times }\end{array}$ & $\begin{array}{r}\text { Usually } \\
\text { all the } \\
\text { time }\end{array}$ \\
\end{tabular}

\section{Transient offences}

You drove over the speed limit in areas where it was unlikely there was a radar or speed camera

You sped up when the lights went yellow

You went too fast around a corner

You did an illegal U-turn

21.5

$$
30.0
$$

25.1

18.2

16.

$$
36.6
$$

22.4

17.5

23.1

$$
47.0
$$

23.5

5.7

.8

You went $10-20 \mathrm{~km} / \mathrm{hr}$ over the speed limit (eg. $72 \mathrm{~km} / \mathrm{hr}$ in a $60 \mathrm{~km} / \mathrm{hr}$ zone, $112 \mathrm{~km} / \mathrm{hr}$ in a $100 \mathrm{~km} / \mathrm{hr}$ zone)

You sped on roads at night that were not well lit

48.8

$$
35.4
$$

You went up to $10 \mathrm{~km} / \mathrm{hr}$ over the speed limit (eg. $65 \mathrm{~km} / \mathrm{hr}$ in a $60 \mathrm{~km} / \mathrm{hr}$ zone, $105 \mathrm{~km} / \mathrm{hr}$ in a $100 \mathrm{~km} / \mathrm{hr}$ zone)

You deliberately sped when overtaking

You overtook a car on the left

$\begin{array}{lllll}43.5 & 31.3 & 16.3 & 7.7 & 1.2\end{array}$

54.5

20.7

36.6

23.2

15.4

34.6

31.0

32.7

22.0

15.9

You spoke on a mobile phone you held in your hands

$\begin{array}{lllll}58.0 & 26.9 & 10.2 & 2.9 & 2.0\end{array}$

You raced out of an intersection when the light went green

$\begin{array}{lllll}21.5 & 38.6 & 22.8 & 13.4 & 3.7\end{array}$

You travelled in the right lane on multilane highways

$\begin{array}{lllll}19.1 & 35.8 & 24.4 & 15.9 & 4.9\end{array}$

You went more than $20 \mathrm{~km} / \mathrm{hr}$ over the speed limit (eg. $60 \mathrm{~km} / \mathrm{hr}$ in a $40 \mathrm{~km} / \mathrm{hr}$ zone, $100 \mathrm{~km} / \mathrm{hr}$ in a $80 \mathrm{~km} / \mathrm{hr}$ zone)

You texted on your mobile phone while driving

$\begin{array}{llllll}70.9 & 19.3 & 6.6 & 2.5 & .8\end{array}$

$\begin{array}{lllll}49.8 & 28.7 & 14.6 & 4.5 & 2.4\end{array}$

\section{Fixed offences}

You carried more passengers than could legally fit in your car

8.1

4.9 
You drove after taking an illicit drug such as marijuana or ecstasy

Your passengers didn't wear seatbelts

You didn't wear a seatbelt if it was only for a short trip

If there was no red light camera, you drove through intersections on a red light

You drove when you thought that you may have been over the legal alcohol limit

You drove a high powered vehicle

You carried more passengers than there were seatbelts for people in your car You drove without a valid licence because you hadn't applied for one yet or it had been suspended

You didn't always wear your seatbelt
92.3

93.5

90.7

92.7

80.2

15.4

4.0

.4

0

86.1

91.1

7.4

4.9

1.2

.4

93.1

2.4

3.7

.4

.4

93.9

2.0

.4

.4 


\section{Table 3}

Self-reported perceptions (proportion, \%) of the frequency of enforcement by police officers of traffic offences $(N=238)$

\begin{tabular}{|c|c|c|c|c|c|}
\hline $\begin{array}{l}\text { How often do you think police officers } \\
\text { enforce the following: }\end{array}$ & Never & $\begin{array}{r}\text { Occasio } \\
\text { nally }\end{array}$ & $\begin{array}{r}\text { Some- } \\
\text { times }\end{array}$ & Usually & $\begin{array}{l}\text { Nearly } \\
\text { all the } \\
\text { time }\end{array}$ \\
\hline Not displaying red P-plates & 10.1 & 31.1 & 22.7 & 24.4 & 11.8 \\
\hline Not displaying green P-plates & 11.0 & 32.1 & 22.8 & 23.6 & 10.5 \\
\hline $\begin{array}{l}\text { Speeding more than } 20 \mathrm{~km} / \mathrm{hr} \text { over the } \\
\text { speed limit }\end{array}$ & 5.5 & 4.2 & 6.1 & 27.3 & 56.3 \\
\hline $\begin{array}{l}\text { Speeding more than } 10 \mathrm{~km} / \mathrm{hr} \text { over the } \\
\text { speed limit }\end{array}$ & 3.4 & 6.4 & 18.6 & 32.2 & 39.4 \\
\hline $\begin{array}{l}\text { Speeding less than } 10 \mathrm{~km} / \mathrm{hr} \text { over the } \\
\text { speed limit }\end{array}$ & 8.9 & 27.1 & 30.1 & 16.5 & 17.4 \\
\hline Not wearing a seat belt & 8.8 & 14.7 & 21.0 & 22.7 & 32.8 \\
\hline $\begin{array}{l}\text { Not carrying a valid Queensland } \\
\text { drivers' licence }\end{array}$ & 6.7 & 14.3 & 15.5 & 20.6 & 42.9 \\
\hline $\begin{array}{l}\text { Driving under the influence of an illicit } \\
\text { drug such as marijuana or ecstasy }\end{array}$ & 8.4 & 9.2 & 10.5 & 15.1 & 56.7 \\
\hline Undertaking an illegal U-turn & 8.0 & 23.1 & 29.8 & 25.2 & 13.4 \\
\hline $\begin{array}{l}\text { Driving through an intersection on a red } \\
\text { light if there was no red light camera }\end{array}$ & 7.6 & 10.5 & 13.9 & 26.5 & 41.6 \\
\hline $\begin{array}{l}\text { Driving through an intersection on a red } \\
\text { light }\end{array}$ & 5.9 & 8.4 & 11.0 & 25.3 & 49.4 \\
\hline Driving over the legal alcohol limit & 5.1 & 3.4 & 4.6 & 16.5 & 70.5 \\
\hline Driving a high powered vehicle & 11.8 & 13.9 & 22.3 & 26.9 & 25.2 \\
\hline Having an illegible licence plate & 11.0 & 12.2 & 21.9 & 29.5 & 25.3 \\
\hline $\begin{array}{l}\text { Talking on a mobile phone that is held } \\
\text { in a person's hand while driving }\end{array}$ & 5.9 & 10.1 & 17.6 & 28.6 & 37.8 \\
\hline $\begin{array}{l}\text { Texting on a mobile phone while } \\
\text { driving }\end{array}$ & 6.3 & 13.1 & 16.5 & 23.2 & 40.9 \\
\hline Traffic laws that apply to all drivers & 4.2 & 7.6 & 19.3 & 38.2 & 30.7 \\
\hline $\begin{array}{l}\text { Traffic laws that apply only to P1 } \\
\text { drivers }\end{array}$ & 4.2 & 11.3 & 15.5 & 32.8 & 36.1 \\
\hline $\begin{array}{l}\text { Traffic laws that apply only to } \mathrm{P} 2 \\
\text { drivers }\end{array}$ & 5.5 & 11.8 & 15.1 & 36.1 & 31.5 \\
\hline
\end{tabular}


Table 4

The effect of driver thrill seeking and perceptions of police enforcement on self-reported transient rule violations

\begin{tabular}{|c|c|c|c|c|c|c|}
\hline \multirow[b]{2}{*}{ Variable } & \multicolumn{3}{|c|}{ Model 1} & \multicolumn{3}{|c|}{ Model 2} \\
\hline & B & Std. Err. & $\beta$ & B & Std. Err. & $\beta$ \\
\hline \multicolumn{7}{|l|}{ Step 1} \\
\hline Gender & -.02 & .09 & -.02 & .10 & .09 & .07 \\
\hline Age & -.04 & .03 & -.09 & -.04 & .03 & -.09 \\
\hline Licence type & .36 & .09 & $.26 * * *$ & .37 & .08 & $.27 * * *$ \\
\hline Police avoidance & -.27 & .08 & $-.19 * *$ & -.18 & .08 & $-.13^{*}$ \\
\hline Previously caught & -.30 & .10 & $-.18 * *$ & -.29 & .09 & $-.18 * *$ \\
\hline Display P-plates & -.19 & .04 & $-.28 * * *$ & -.19 & .04 & $-.26 * * *$ \\
\hline \multicolumn{7}{|l|}{ Step 2} \\
\hline Driver thrill seeking & & & & .11 & .02 & $.31 * * *$ \\
\hline Police enforcement & & & & -.02 & .04 & -.02 \\
\hline$R^{2}$ & & & $.27 * * *$ & & & $.35 * * *$ \\
\hline Adjusted $R^{2}$ & & & .25 & & & .33 \\
\hline$R^{2}$ change & & & .27 & & & .09 \\
\hline$F$ change & & & $13.74 * * *$ & & & $14.73 * * *$ \\
\hline Df & & & 6 & & & 2 \\
\hline
\end{tabular}

Note: ${ }^{*} p<.05 ; * * p<.01 ; * * * p<.001$. 


\section{Table 5}

The effect of driver thrill seeking and perceptions of police enforcement on self-reported fixed rule violations

\begin{tabular}{|c|c|c|c|c|c|c|}
\hline \multirow[b]{2}{*}{ Variable } & \multicolumn{3}{|c|}{ Model 1} & \multicolumn{3}{|c|}{ Model 2} \\
\hline & B & Std. Err. & $\beta$ & B & Std. Err. & $\beta$ \\
\hline \multicolumn{7}{|l|}{ Step 1} \\
\hline Gender & -.06 & .05 & -.08 & -.02 & .05 & -.02 \\
\hline Age & .02 & .02 & .07 & .01 & .02 & .05 \\
\hline Licence type & -.05 & .05 & -.07 & -.02 & .05 & -.03 \\
\hline Police avoidance & -.08 & .05 & -.11 & -.06 & .05 & -.08 \\
\hline Previously caught & -.11 & .05 & $-.14^{*}$ & -.10 & .05 & $-.13^{*}$ \\
\hline Display P-plates & -.10 & .02 & $-.29 * * *$ & -.09 & .02 & $-.27 * * *$ \\
\hline \multicolumn{7}{|l|}{ Step 2} \\
\hline Driver thrill seeking & & & & .02 & .01 & $.12^{+}$ \\
\hline Police enforcement & & & & -.07 & .02 & $-.18 * *$ \\
\hline$R^{2}$ & & & $.16^{* * *}$ & & & $.20 * * *$ \\
\hline Adjusted $R^{2}$ & & & .13 & & & .17 \\
\hline$R^{2}$ change & & & .16 & & & .04 \\
\hline$F$ change & & & $6.94 * * *$ & & & $6.02 * *$ \\
\hline $\mathrm{df}$ & & & 6 & & & 2 \\
\hline
\end{tabular}

